\title{
The Strict Liability by Corporate in Enforcement of Environmental Law
}

\section{Purnomo Wulandari*) and Sri Endah Wahyuningsih*)}

*) Student of Master of Law Program, Faculty of Law Universitas Islam Sultan Agung, and Prosecutors at the Semarang City District Attorney email wulan 2719@yahoo.co.id

**) Faculty of Law Universitas Islam Sultan Agung

\begin{abstract}
.
The purpose of this study is to determine and describe the strict liability of corporations in environmental law enforcement. The research method used is a normative juridical approach and is descriptive analytical in nature. The data used in this research is secondary data, which is obtained through literature study and analyzed to obtain qualitative data. The conclusion of this study is that strict liability is an accountability without an element of error, where the element of error does not need to be proven by the plaintiff as a basis for compensation payments. The perpetrator or polluter has sufficiently been declared responsible for pollution or environmental destruction, even though the perpetrator has not been found guilty. The concept of strict liability is indirectly an embodiment of legal protection for society, which is the part that has the potential to be harmed as a result of industrial activities carried out. Strict liability arrangements by corporations are stated in Article 88 of Act No. 32 of 2009. The amount of compensation that can be imposed on environmental polluters or destroyers can be determined to a certain extent.

Keywords: Environmental Law; Corporation; Law Enforcement; Strict Liability.
\end{abstract}

\section{Introduction}

The Unitary State of the Republic of Indonesia is a country that has environmental problems that are very concerning, this can be seen from the many cases of environmental pollution and destruction that have had a very big impact on society and the environment itself, this cannot be separated from human activities that tend to ignore the environment.

The environmental elements which are the target of human activities, together form a unitary environmental system through a very complex network of relationships, where disturbance of one element of the formation of the environmental system will change its formation. ${ }^{1}$

Arief Hidayat argued that the relationship between humans and the environment forms a separate system which is termed an ecosystem. This relationship runs on the principle of balance harmony, where disruption of this balance will have an impact on the balance of the ecosystem. Humans as active actors in maintaining this balance have been provided with 'logical reasoning' and 'conscience' which have accumulated into environmental wisdom. Unfortunately,

\footnotetext{
${ }^{1}$ Pongtuluran, Yonathan. (2014). Manajemen Sumber Daya Alam dan Lingkungan. Yogyakarta: Andi Offset. p. 16.
} 
the potential for environmental wisdom is co-opted by various political, economic, social and cultural interests of the community and law enforcers. ${ }^{2}$

The emergence of environmental cases that have occurred in various parts of the world cannot be separated from human exploitative attitudes and behavior towards the environment. Such attitudes and behaviors are nothing but the implications of the persistence of views that place humans and their interests at the center of everything.

Humans are considered to be the most decisive in the ecosystem order, so that humans can do anything to the environment, even in ways that damage the environment. As a result, now what is known as an environmental crisis, such as water crisis, clean air, extinction of animals, and so on. This crisis has become one of the 'contributors' to a serious global crisis. ${ }^{3}$

Environmental problems caused by human activity that occur in various parts of the world, including in Indonesia, have seriously threatened the existence of human life and life. This problem will continue if humans as the main component of the environment do not do their best to solve environmental problems, such as pollution and environmental damage.

Thousands or even millions of years ago humans lived without worrying about the disturbance or danger of air pollution, water pollution, or environmental pollution as it is currently being questioned, because humans believed and believed in the ability of natural systems to deal with them naturally. However, with the rapid development of industry, pollution is increasingly occurring, especially the disposal of corporate waste which is carried out in rivers and in the sea.

Anyone who pollutes and damages the environment means that he has violated the laws and regulations governing the environment, namely Act No. 32 of 2009 concerning Environmental Protection and Management. Especially for corporations that do a little harm to the environment with their activities. An example of environmental pollution by corporations is the case of the Lapindo mudflow, the pollution of Buyat Bay by PT. Newmont Minahasa Raya, and so on. Environmental pollution not only harms the environment but also the surrounding community, so that the corporation must be held accountable for its actions.

Literally, corporation comes from the word corporatio in Latin. Corporation is a term commonly used by criminal law experts to refer to what is in civil law as a legal entity (recht person) and in English legal entities or corporations. The old doctrine of criminal law places that humans are the only subject of criminal law, the doctrine of the universality of delenquere non-potest is still valid, but with the development of the corporation the old doctrine has shifted through the acceptance of the concept of functionale dader-schap. ${ }^{4}$

Corporations do make a lot of contributions to the development of a country, especially in the economic field. However, on the other hand, as mentioned,

\footnotetext{
2 Renggong, Ruslan. (2018). Hukum Pidana Lingkungan. Cetakan Pertama. Jakarta: Kencana Prenada Media. p. 2.

3 Akib, Muhammad. (2015). Penegakan Hukum Lingkungan Dalam Perspektif Holistik-Ekologis. Yogyakarta: Graha Ilmu. p. 1.

${ }^{4}$ Setiadi, Edi and Rena Yulia. (2010). Hukum Pidana Ekonomi. Edisi Pertama. Yogyakarta: Graha Ilmu. p. 58.
} 
corporations often create negative impacts such as pollution and environmental damage. The impact of corporate activities that pollute and damage the environment can be fast, long, even continuous. Corporations tend to carry out activities that violate regulations to achieve their goals, so it is very appropriate if corporations become the subject of criminal acts besides humans.

According to Satjipto Rahardjo, the placement of corporations as subjects in criminal law cannot be separated from social modernization. The impact of modernization is that the more modern society is, the more complex the social, economic and political systems that exist in that society. Therefore, it requires a neat organized, clear and detailed arrangement. ${ }^{5}$

In the perspective of criminal law, pollution and damage to the environment is one form of criminal action in the environmental sector. Perpetrators of criminal acts are clarified in Article 1 point 32 of Act No. 32 Of 2009, which states that: "Every person is an individual or business entity, either legally incorporated or not." Thus, corporations or business entities can become perpetrators of environmental crimes. Responsibility or sanctions for corporations in environmental pollution consists of administrative responsibility, civil responsibility, and criminal responsibility. ${ }^{6}$

The enactment of Act No. 32 of 2009 is a reference for law enforcement officials in order to provide a basis on which to base their footing on the perpetrators of violations that pollute the environment in society. Thus, it will be able to provide lessons as well as become a law that functions as an oversight in society in order to maintain the existing environmental spirit. In enforcing the law in Act No. 32 of 2009 using the principle of absolute responsibility (strict liability), in which the explanation is that strict liability is an element of error that does not need to be proven by the plaintiff as a basis for compensation payments. This becomes very important because this arrangement is special, especially in this principle.

The purpose of this research is to know and describe about strict liability by corporations in environmental law enforcement.

\section{Research methods}

The approach method used in this research is the normative juridical approach, which is an approach that seeks to synchronize the prevailing legal provisions in legal protection against norms or other legal regulations with their relation to the application of these legal regulations in practice. in the field, ${ }^{7}$ in this case related to the strict liability by corporations in environmental law enforcement. This research is descriptive analysis, because the researcher wishes to describe or describe the subject and object of the research, which then analyzes and finally draws conclusions from the results of the study. ${ }^{8}$ The data used in this research is

\footnotetext{
5 Syahrin, Alvi Martono Anggusti, and Abdul Aziz Alsa. (2019). Ketentuan Pidana Korporasi Tentang Perlindungan dan Pengelolaan Lingkungan Hidup. Jakarta: Kencana Prenada Media Group. p. 23.

${ }^{6}$ Natsir, Muhammad (2019). Korporasi Antara Sanksi dan Tindak Pidana Lingkungan Di Aceh. Cetakan Pertama. Yogyakarta: Deepublish. p. 24.

${ }^{7}$ Asofa, Burhan. (2001). Metode Penelitian Hukum. Jakarta: Rineka Cipta. p. 15.

${ }^{8}$ Fajar ND, Mukti and Yulianto Achmad. (2010). Dualisme Penelitian Hukum Normatif dan Empiris. Yogyakarta: Pustaka Pelajar. p. 183.
} 
secondary data. Secondary data is data obtained from library materials through library research, and this data is also obtained from agencies/institutions related to the purpose of this research. ${ }^{9}$ According to the data obtained during the research by reading library books, then analyzed. The analysis used in this research is qualitative data analysis.

\section{Result and Discussion}

Humans have a reciprocal relationship with their environment. Its activities affect the environment. On the contrary, humans are influenced by their environment. Such reciprocal relationships exist between humans as individuals or groups or communities and their natural environment. ${ }^{10}$ Referring to Act No. 32 of 2009 , it explains that each of these activities is required to ensure the sustainability of environmental functions. ${ }^{11}$ The environment (enviroment or habitat) is a complex system in which various factors influence each other and with society and plants. ${ }^{12}$

At present, environmental management is mostly carried out by corporations, not the least by individuals. Currently, the land, apart from protected forest, is almost entirely controlled by owners of land use rights or building use rights, which are generally owned by individuals, corporations or BUMN/BUMD which are legal entities resulting from legal creations, so that their death or existence determined by law. ${ }^{13}$

Structurally, the government opens up opportunities by issuing environmental management principle permits. For example, the Ministry of Forestry issues a mining permit $\mathrm{C}$, if there is environmental damage they don't care, because they have already pocketed the permit, it is legally correct, but then when exploration and exploitation is found in gas and oil or high-priced materials, they greedily do not only destroy forest but at the same time digging roughly, this is clearly a structural fault because there will be more damage. In this case the actors can be categorized as structurally as the executive or legislative, ${ }^{14}$ so that to overcome this, a legal rule is needed that can ensnare any party who violates it.

\footnotetext{
${ }^{9}$ Soeratno and Lincolin Arsyad. (2003). Metodologi Penelitian Untuk Ekonomi Dan Bisnis. Yogyakarta: UPP AMP YKPN. p. 173.

10 Silalahi, M. Daud. (2014). Hukum Lingkungan Dalam Sistem Penegakan Hukum Lingkungan Indonesia. Cetakan Ketiga. Bandung: Alumni. p. 9-10.

11 Idayatama, Widya Putri and Rakhmat Bowo Suharto. June (2019). Economic Integration And Environment In Organizing Ports Services (Management Of Juridical Analysis Of Tanjung Emas Port In Semarang. Jurnal Daulat Hukum, Vol. 2 No. 2, Faculty of Law. Universitas Islam Sultan Agung, Semarang. url: http://jurnal.unissula.ac.id/index.php/RH/article/ view/5658/3380. p. 296.

12 Suroto and Gunarto. March 2018. Dampak Penambangan Pasir Besi Di Desa Bandungharjo, Banyumanis Dan Ujungwatu Kabupaten Jepara Menurut UU No. 32 Tahun 2009 Tentang Perlindungan Dan Pengelolaan Lingkungan Hidup. Jurnal of Daulat Hukum, Vol. 1. No. 1. Fakultas Hukum. Universitas Islam Sultan Agung Semarang, url: http: //jurnal.unissula. ac.id/index.php/RH/article/view/2644/1988. p. 258.

13 Muchtar, Masrudi. (2015). Sistem Peradilan Pidana di Bidang Perlindungan dan Pengelolaan Lingkungan Hidup. Jakarta: Prestasi Pustaka. p. 111.

${ }^{14}$ Ibid, p. 112.
} 
Activities in environmental management are mostly carried out by corporations, so that the corporation will become the subject of criminal acts and there are many laws and regulations that regulate it, but there are still different ones that stipulate only the management can be held accountable and some also declare the corporation a legal subject. so that this can be accounted for, including Act No. 32 of 2009.15

The environment in the field of legal science is one of the most strategic fields of legal science because environmental law has three aspects, namely aspects of administrative law, aspects of criminal law, and aspects of civil law, besides that to maximize environmental law it must be implemented by various institutions because of the relationship between laws of environment with other laws. ${ }^{16}$

Enforcement of environmental law is important for the sake of upholding environmental law, in this case Act No. 32 of 2009, therefore environmental law enforcement is indiscriminate. Anyone who violates environmental law will be given sanctions according to the severity and lightness of his actions, this is very important because in recent decades pollution and environmental damage in Indonesia has gotten worse so that the way to go is to follow. indiscriminate enforcement of environmental laws, especially actions taken by corporations that only seek profit without paying attention to environmental aspects. The rule of law is at the same time an indicator of the rule of law. ${ }^{17}$ Consistent law enforcement will provide a sense of security, justice and certainty. ${ }^{18}$ Law enforcers are required to carry out their duties in accordance with the mandate of laws and regulations which lead to decisions with the substance of justice for the parties. ${ }^{19}$

In the environmental law enforcement system in Indonesia, there are three legal aspects described in Act No. 32 of 2009, namely aspects of administrative law, civil law and criminal law. Law enforcers for each different aspect, namely the administrative aspect by administrative or government officials, the civil aspect by the injured party either individually or in groups, even the community or the state itself in the name of the public interest, while the criminal aspect whose prosecution is monopolized by the state the tool is the prosecutor as the personification of the state. ${ }^{20}$

15 Arif, Barda Nawawi. (2010). Kapita Selekta Hukum Pidana. Bandung: Citra Aditya Bakti. p. 234.

16 Rahmadi, Takdir. (2014). Hukum Lingkungan di Indonesia. Jakarta: Raja Grafindo Persadap. p. xii.

17 Syahri, Alvi September. (2020). Law Enforcement against Policies Who Breached the Code of Conduct. Jurnal Daulat Hukum. Vol. 3 No. 3. Fakultas Hukum Universitas Islam Sultan Agung, Semarang. url: http://jurnal.unissula.ac.id/index.php/RH/article/view/11238/4399. p. 313.

18 Praptiwi, Anggrin Gayuh and Lathifah Hanim. September (2019). Effectiveness And Role Of The Food Duty Unit Of Police Region Of Central Java In Law Enforcement In The Field Of Food In The Regional Law Of POLDA Central Java. Jurnal Daulat Hukum. Vol. 2 No. 3. Fakultas Hukum Universitas Islam Sultan Agung, Semarang. url: http://jurnal.unissula.ac.id/ index.php/RH/article/view/5669/3416. p. 387.

19 Setiyadi, Iwan and Sri Kusriyah. June (2019). Law Enforcement Process Analysis By Agencies Of Provos Indonesian National Police (Inp) On Discipline Violation In The Form Of Crime By Police Members (Case Study In National Police Headquarter). Jurnal Daulat Hukum, Vol. 2 No. 2. Fakultas Hukum Universitas Islam Sultan Agung, Semarang. url: http: // journal. unissula.ac.id/index.php/RH/article/view/5424/3345. p. 204.

20 Yanto, Nur. (2018). Pengantar Hukum Lingkungan Di Indonesia. Edisi Pertama. Jakarta: Mitra Wacana Media. p. 70. 
Corporations for their activities that pollute and damage the environment can be held accountable. To prove a fault in a corporation is very difficult, because it is generally accepted that people have mistakes, ${ }^{21}$ so that in order to facilitate the corporate responsibility system, it is necessary to consider the application of the principle of strict liability.

In Indonesia, there are two forms of civil accountability, namely ordinary (general) and special accountability. ${ }^{22}$ The legal basis for ordinary (general) responsibility is contained in Article 87 paragraph (1) of Act No. 32 of 2009 which reads: "Every person in charge of a business and/or activity commits an illegal act in the form of pollution and/or environmental destruction. which causes harm to other people or the environment is obliged to pay compensation and/or take certain actions ". The article regulates the liability for environmental pollution in general which is based on acts against the law. Acts against the law are regulated in Article 1365 of the Civil Code (KUHPerdata), which states that every act against the law, which brings harm to other people, obliges the person who due to his wrongdoing to issue the loss, to compensate the loss.

Article 88 paragraph (1) of Act No. 32 Of 2009 regulates specific responsibilities that apply the principle of strict liability or liability without fault, namely responsibility without any element of error, and what is meant by "responsibility. Absolute"or strict liability is an element of error that does not need to be proven by the plaintiff as a basis for compensation payments. The provisions of this paragraph constitute lex specialis in a lawsuit concerning acts of violating the law in general.

The amount of compensation that can be charged against environmental polluters or destroyers according to Article 88 paragraph (1) of Act No. 32 Of 2009 can be determined to a certain extent. Then what is meant by "up to a certain time limit" is if according to the stipulation of laws and regulations, insurance requirements for the business and/or activity concerned or environmental funds are available. The principle of absolute responsibility/strict liability has never been applied in Indonesia. Even though this concept is very good for maintaining the survival of the people who are victims. The elements in strict liability contained in Article 35 paragraph (1) of Act No. 32 Of 2009 are: ${ }^{23}$

- An act or activity;

- Has a large and important impact on the environment;

- Using or producing hazardous and toxic materials/waste;

- Liability arises absolutely;

- Direct and immediate responsibility at the time of environmental pollution/destruction.

The concept of strict liability is needed in Indonesia. Given that this system departs from the demands of technological developments and modernization. Based on this principle, the perpetrator or the polluter has sufficiently been declared

\footnotetext{
${ }^{21}$ Priyatno, Dwidja. (2017). Sistem Pertanggungjawaban Pidana Korporasi Dalam Kebijakan Legislasi. Cetakan Kesatu. Depok: Kencana Prenada Media. p. 106.

22 Siahaan, NHT. (2004). Hukum Lingkungan dan Ekologi Pembangunan. Edisi Kedua. Jakarta: Erlangga. p. 310.

${ }^{23}$ Ibid. p. 271.
} 
responsible for environmental pollution or destruction, even though the perpetrator has not been found guilty. Because in the principle of strict liability, the element of error/mens rea is not important to hold the perpetrator responsible because when the incident occurred he already had a responsibility. When these events arise, the principle of res ipso loquitur applies, which is a fact that speaks for itself (the thing speaks for itself). Strict liability is deemed necessary in modern legal traffic to enable the carrying out of various activities that carry overly large responsibilities (extra hazardous activity, ultra hazardous, abnormally dangerous), but from the perspective of society (international), it can be considered beneficial, so that if without the application of strict liability it is deemed not to provide a legal protection for the perpetrator (polluter) and the victim. Strict liability can give responsibility to a person who carries out the types of activities classified as above, so he is also obliged to bear all the losses incurred which in reality on the ground he has acted very carefully (utmost care), to prevent the danger or loss even though done accidentally. ${ }^{24}$

LB Curzon in his book Criminal Law, describes the actuality and benefits of the principle of strict liability. According to Curzon this principle is needed with regard to: 25

- The importance of guarantees to comply with certain important rules necessary for the welfare of society. This guarantee can provide legal certainty to the community, and indirectly the emergence of a guarantee results in the entrepreneur being obliged to be aware of the existence of laws regulating the per-accountability system;

- Evidence of guilt is very difficult to obtain for violations of regulations related to the welfare of the community. And not infrequently, the evidence is lost or destroyed. So there is a need for strict liability in responding to a case so that the welfare of the community is indirectly fulfilled;

- A high level of social danger as a result of these actions. These dangers can cause social upheaval within the body of society itself, of course this is very dangerous because it can cause material and material harm. The law must and must provide preventive action before the turmoil occurs. For the sake of the survival of the nation and state.

Curzon realized that it is increasingly difficult to obtain evidence for certain cases, while the (criminal) act poses a high level of danger to the welfare of society.

The use of strict liability as a new legal system, the obstacles experienced by the sufferer can be minimized, then another thing that can be taken as something that benefits the victim is assumptively the perpetrator has been declared responsible, regardless of whether he is guilty or not. This is a very rapid development in legal science. Because so far, the element of error (fault, mens rea) has always been the main choice in the basis of liability for claims of a loss.

24 Santosa, Mas Achmad. (1998). Undang-Undang Nomor 23 Tahun 1997 tentang Pengelolaan Lingkungan Hidup dan Bahayanya. Proyek Pembinaan Teknis Yustisi Mahkamah Agung. Jakarta: Mahkamah Agung. p. 125.

25 Edhita Praja, Chrisna Bagus Dasep Nurjaman, Dian Arifa Fatimah, and Nilma Himawati. March (2016). Strict Liability as an Environmental Law Enforcement Instrument. Varia Justicia. Vol. 12 No. 1, p. 53. 
In absolute responsibility, the element of error does not need to be proven by the plaintiff as a basis for paying compensation. This provision is a lex specialis in a lawsuit about illegal acts in general. The amount of compensation that can be imposed on environmental polluters and/or destroyers can be determined to a certain extent. ${ }^{26}$ In this case, the strict (absolute) liability which leaves the principle of mens rea is a reflection of the tendency to maintain a balance of social interests. ${ }^{27}$

In the field of civil law, the principle of absolute responsibility (strict liability) is one type of civil liability. ${ }^{28}$ Civil liability in the context of environmental law enforcement is a civil law instrument in the context of obtaining compensation and costs for environmental restoration due to environmental pollution and/or damage caused. The principle of absolute responsibility (strict liability) in Indonesian is often translated as absolute responsibility. In addition, it also translates into immediate and direct responsibility. It means immediate responsibility because it implies that the defendant's responsibility must be carried out immediately and directly without having to wait for a court ruling that finds the defendant guilty.

The principle of strict liability is a principle of legal responsibility (liability) that has been developing since a long time ago. The principle was born from a case in England (Rylands v. Fletcher) in 1868. Since then various countries of the world have begun to accommodate this principle in their every legal system. In this case, Indonesia is a country that subject itself to this principle. The principle of absolute absolute responsibility (strict liability) is an idea conveyed in Article 88 of Act No. 32 Of 2009, namely: "Every person whose actions, business and/or activities use B3, produce and/or manage B3 waste, and/or those that pose a serious threat to the environment are absolutely responsible for the losses incurred without the need to prove the element of error ".

In the elucidation of Article 88 of Act No. 32 Of 2009, it is stated that what is meant by absolute responsibility is "the element of error does not need to be proven by the plaintiff as a basis for compensation payment". In view of the law, the need for proof is a special rule (lex specialis) rather than an act of breaking the law, this is because general violations have a burden of proof for the plaintiff. The elements in Article 88 of Act No. 32 of 2009 also clearly state that Article 88 of Act No. 32 of 2009 actually characterizes the main characteristic of strict liability, where in the regulations there is a clause which explains that in its emergence responsibility at the time of the action, ${ }^{29}$

The issue of environmental damage is part of a dangerous activity, so that strict liability doctrine is very important to be implemented, not because the aggrieved party has to explain, in this case it is the defendant who must be able to explain the errors resulting from the environmental damage it produces. ${ }^{30}$

It cannot be denied that the impact of environmental damage is a serious concern which is also a consideration for why strict liability is a principle that must

\footnotetext{
${ }^{26}$ Renggong, Ruslan. op.cit. p. 93.

${ }^{27}$ Machmud, Syahrul. (2012). Penegakan Hukum Lingkungan Indonesia. Yogyakarta: Graha Ilmu. p. 140.

${ }^{28}$ HS, Salim. (2008). Pengantar Hukum Perdata Tertulis (BW). Jakarta: Sinar Grafika. p. 45.

${ }^{29}$ Siahaan, NHT. loc.cit. p. 310.

${ }^{30}$ Ibid.
} 
be applied. Considering that the resulting impact is very risky for the community, this principle should naturally exist in the framework of law enforcement in Indonesia, especially in terms of management and protection in the dimension of environmental law.

In the literature, environmental problems can be grouped into three forms, namely environmental pollution, land misuse and natural resource depletion. However, if viewed from the perspective of the prevailing laws in Indonesia, environmental problems can be grouped into two forms, namely environmental pollution and environmental destruction. ${ }^{31}$

The liability perspective in civil liability recognizes 2 (two) types of accountability, namely accountability which requires proof of an element of error that causes a loss (fault based liability) and absolute responsibility (strict liability), an accountability without having to prove the existence of an element of error. , where responsibility and compensation appear immediately after the act is committed. In the concept of accountability, which requires proof of an element of error (fault based liability), in civil terms it is in Article 1365 of the Civil Code. In Indonesia this is known as an illegal act (PMH). This concept requires that in order to hold accountable, then it must be able to prove the elements of the error committed by the defendant. Including this concept, when applied to existing environmental disputes, it will create difficulties for the community. Environmental impacts that come from economic activities, for example, often have a large profit and being able to carry out and overcome prudence becomes an obstacle for the small and common people around the environment. With the limitations of society, often small communities are in a weak and subordinate position. Moreover, if damage occurs, they must be sued to prove the existence of a mistake in order to prove the defendant's guilt. Therefore, this concept is actually very irrelevant in the law enforcement model. The concept of strict liability in civil law, this model is actually relevant to what is regulated in Article 1367 paragraph (3) of the Civil Code regarding the responsibility of employers and the accountability of building owners. This accountability concept is also known as risk liability (risicoaansprakelijkheid). ${ }^{32}$

The concept of strict liability is indirectly an embodiment of legal protection for the community, which incidentally is a part that has the potential to be harmed as a result of industrial activities carried out.

\section{Closing}

The principle of strict liability (absolute responsibility) or liability without fault, namely responsibility without an element of error, and what is meant by "absolute responsibility" or strict liability is an element of error that does not need to be proven by the plaintiff as the basis for compensation payments. The provisions of this paragraph constitute lex specialis in lawsuits regarding acts of violation of the law in general. The regulation of absolute liability (strict liability) by corporations in Act No. 32 of 2009 as stated in Article 88 of Act No. 32 of 2009, that:

\footnotetext{
31 Rahmadi, Takdir. op.cit. p. 1.

32 Rangkuti, Siti Sundari. (1996). Hukum Lingkungan dan Kebijaksanaan Lingkungan Nasional. Surabaya: Airlangga University Press. p. 270-280.
} 
"Every person whose actions, business, and/or activities use B3, produce and/or managing B3 waste, and/or which pose a serious threat to the environment, are absolutely responsible for the losses incurred without the need for proof of guilt". The amount of compensation that can be charged against environmental polluters or destroyers according to Article 88 paragraph (1) of Act No. 32 Of 2009 can be determined to a certain extent. The purpose of "up to a certain time limit" is if according to the stipulation of laws and regulations, insurance requirements for the business and/or activity concerned or environmental funds are available, this system departs from the demands of technological development and modernization. Based on this principle, the perpetrator or the polluter has been sufficiently declared responsible for environmental pollution or destruction, even though the perpetrator has not been found guilty. The concept of strict liability is indirectly an embodiment of legal protection for the community, which incidentally is a part that has the potential to be harmed as a result of industrial activities carried out.

Strict liability can be applied in the Indonesian criminal law system, especially in criminal acts that cause large losses and have a very broad impact on society, which are committed by corporations.

\section{References}

\section{Journals}

[1] Edhita Praja, Chrisna Bagus Dasep Nurjaman, Dian Arifa Fatimah, and Nilma Himawati. March (2016). Strict Liability as an Environmental Law Enforcement Instrument. Varia Justicia. Vol. 12 No. 1.

[2] Idayatama, Widya Putri and Rakhmat Bowo Suharto. June (2019). Economic Integration And Environment In Organizing Ports Services (Management of Juridical Analysis of Tanjung Emas Port In Semarang. Jurnal Daulat Hukum, Vol. 2 No. 2, Faculty of Law. Universitas Islam Sultan Agung, Semarang. url: http://jurnalunissula.ac.id/index.php/RH/article/ view/5658/3380.

[3] Imamulhadi. October (2013). Perkembangan Prinsip Strict Liability dan Preacautionary Dalam Penyelesaian Sengketa Lingkungan Hidup Di Pengadilan. Mimbar Hukum, Vol. 25 No. 3.

[4] Praptiwi, Anggrin Gayuh and Lathifah Hanim. September (2019). Effectiveness And Role of The Food Duty Unit Of Police Region Of Central Java In Law Enforcement In The Field of Food In The Regional Law Of POLDA Central Java. Jurnal Daulat Hukum. Vol. 2 No. 3. Fakultas Hukum Universitas Islam Sultan Agung, Semarang. url: http://jurnal.unissula.ac.id/ index.php/RH/article/view/5669/3416.

[5] Setiyadi, Iwan and Sri Kusriyah. June (2019). Law Enforcement Process Analysis By Agencies Of Provos Indonesian National Police (Inp) On Discipline Violation In The Form of Crime By Police Members (Case Study In National Police Headquarter). Jurnal Daulat Hukum, Vol. 2 No. 2. Fakultas Hukum Universitas Islam Sultan Agung, Semarang. url: http: // journal. unissula.ac.id/index.php/RH/article/view/5424/3345. 
[6] Suroto and Gunarto. March 2018. Dampak Penambangan Pasir Besi Di Desa Bandungharjo, Banyumanis Dan Ujungwatu Kabupaten Jepara Menurut UU No. 32 Tahun 2009 Tentang Perlindungan Dan Pengelolaan Lingkungan Hidup. Jurnal Daulat Hukum, Vol. 1. No. 1. Fakultas Hukum. Universitas Islam Sultan Agung Semarang, url http: //jurnalunissula. ac.id/index.php/RH/article/view/2644/1988.

[7] Syahri, Alvi September. (2020). Law Enforcement against Policies Who Breached the Code of Conduct. Jurnal Daulat Hukum. Vol. 3 No. 3. Fakultas Hukum Universitas Islam Sultan Agung, Semarang. url: http://jurnal.unissula.ac.id/index.php/RH/article/view/11238/4399.

\section{Books}

[1] Akib, Muhammad. (2015). Penegakan Hukum Lingkungan Dalam Perspektif Holistik-Ekologis. Yogyakarta: Graha Ilmu.

[2] Arif, Barda Nawawi. (2010). Kapita Selekta Hukum Pidana. Bandung: Citra Aditya Bakti.

[3] Asofa, Burhan. (2001). Metode Penelitian Hukum. Jakarta: Rineka Cipta.

[4] Fajar ND, Mukti and Yulianto Achmad. (2010). Dualisme Penelitian Hukum Normatif dan Empiris. Yogyakarta: Pustaka Pelajar.

[5] HS, Salim. (2008). Pengantar Hukum Perdata Tertulis (BW). Jakarta: Sinar Grafika.

[6] Machmud, Syahrul. (2012). Penegakan Hukum Lingkungan Indonesia. Yogyakarta: Graha Ilmu.

[7] Muchtar, Masrudi. (2015). Sistem Peradilan Pidana di Bidang Perlindungan dan Pengelolaan Lingkungan Hidup. Jakarta: Prestasi Pustaka.

[8] Natsir, Muhammad (2019). Korporasi Antara Sanksi dan Tindak Pidana Lingkungan Di Aceh. Cetakan Pertama. Yogyakarta: Deepublish.

[9] Pongtuluran, Yonathan. (2014). Manajemen Sumber Daya Alam dan Lingkungan. Yogyakarta: Andi Offset.

[10] Priyatno, Dwidja. (2017). Sistem Pertanggungjawaban Pidana Korporasi Dalam Kebijakan Legislasi. Cetakan Kesatu. Depok: Kencana Prenada Media.

[11] Rahmadi, Takdir. (2014). Hukum Lingkungan di Indonesia. Jakarta: Raja Grafindo Persadap.

[12] Rangkuti, Siti Sundari. (1996). Hukum Lingkungan dan Kebijaksanaan Lingkungan Nasional. Surabaya: Airlangga University Press.

[13] Renggong, Ruslan. (2018). Hukum Pidana Lingkungan. Cetakan Pertama. Jakarta: Kencana Prenada Media.

[14] Santosa, Mas Achmad. (1998). Undang-Undang Nomor 23 Tahun 1997 tentang Pengelolaan Lingkungan Hidup dan Bahayanya. Proyek Pembinaan Teknis Yustisi Mahkamah Agung. Jakarta: Mahkamah Agung.

[15] Setiadi, Edi and Rena Yulia. (2010). Hukum Pidana Ekonomi. Edisi Pertama. Yogyakarta: Graha Ilmu.

[16] Siahaan, NHT. (2004). Hukum Lingkungan dan Ekologi Pembangunan. Edisi Kedua. Jakarta: Erlangga.

[17] Silalahi, M. Daud. (2014). Hukum Lingkungan Dalam Sistem Penegakan Hukum Lingkungan Indonesia. Cetakan Ketiga. Bandung: Alumni. 
[18] Soeratno and Lincolin Arsyad. (2003). Metodologi Penelitian Untuk Ekonomi Dan Bisnis. Yogyakarta: UPP AMP YKPN.

[19] Syahrin, Alvi Martono Anggusti, and Abdul Aziz Alsa. (2019). Ketentuan Pidana Korporasi Tentang Perlindungan dan Pengelolaan Lingkungan Hidup. Jakarta: Kencana Prenada Media Group.

[20] Yanto, Nur. (2018). Pengantar Hukum Lingkungan Di Indonesia. Edisi Pertama. Jakarta: Mitra Wacana Media. 